\title{
Pulmonary mechanics and diffusion after 'shock lung'
}

\author{
J.C. YER NAULT, M. EN GLERT, R. SER G Y S E LS, \\ a n d A. D E COSTER
}

Departments of Pneumology and Cardiology, Hôpital Universitaire Saint Pierre, Rue Haute, 322, 1000 Brussels, Belgium

\begin{abstract}
Yernault, J. C., Englert, M., Sergysels, R., and de Coster, A. (1975). Thorax, 30, 252-257. Pulmonary mechanics and diffusion after 'shock lung'. Pulmonary function studies performed in seven patients who had recovered from 'shock lung' showed a highly significant decrease of diffusing properties of the lung, a slight loss of lung recoil pressure, and a borderline increase of residual volume with normal vital capacity and total lung capacity. Pulmonary compliance was normal. The interpretation of these findings is discussed.
\end{abstract}

'Shock lung' (Proctor, Ballantine, and Broussard, 1970 ) is a syndrome of severe respiratory insufficiency accompanying shock of several aetiologies (trauma, hypovolaemia, haemorrhage, sepsis, etc.). The clinical evolution of the acute period can be roughly divided into four stages (Moore et al., 1969; Gay and Campan, 1972; de Coster et al., 1974):

1. Shock is treated by massive intravenous infusion. Hyperventilation with hypocapnia is sometimes present.

2. Moderate hypoxaemia appears some hours or days after haemodynamics have returned to normal; it resolves or progresses to stage 3.

3. Distress, tachypnoea, and cyanosis develop. Radiography shows mottled opacities which progressively opacify the entire lung. In spite of artificial ventilation with pure oxygen, arterial oxygen pressure remains low.

4. Severe hypoxaemia persists and eventually hypercapnia, loss of consciousness, and death.

The pathophysiology of this syndrome is still debated. Functional studies made during the acute period have shown a lowered pulmonary compliance (Henry et al., 1967; Cahill et al., 1965; Wilson et al., 1969; Proctor et al., 1970); diffusing properties of the lung have not been studied.

The aim of the present study was to evaluate the physiological sequelae in patients who had completely recovered from the acute syndrome.

'Work partially realized under contract of the 'Ministère de la Politique Scientifique' within the framework of the Association Euratom-University of Brussels-University of Pisa, and with the financial aid of the CEE (Luxembourg)

\section{MATERIAL AND METHODS}

Of 12 patients hospitalized in the medical inteno sive care unit of our hospital for shock lung syno drome from 1971 to 1973 eight have completel 2 recovered. Seven of them have been studied afte recovery one to 20 months after the acute period $\overline{3}$

The clinical and therapeutic problems have beew reported elsewhere (de Coster et al., 1974) and are summarized in Table I. It should be empha sized that none of the patients had a history of previous pulmonary disease. At the time of the study physical examination and chest radiograph were normal in all patients and all were symptom free except case 6 , who complained of slight exero tional dyspnoea.

The biometric characteristics of the subjects studied are reported in Table I, together with the time, in months, after the acute phase before the physiological studies were performed.

Vital capacity (VC) and one-second forced ex piratory volume $\left(\mathrm{FEV}_{1}\right)$ were measured with conventional spirometer. Functional residuai capacity (FRC) was measured by the helium dilu $\mathrm{K}$ tion method. Predicted values for lung volume were calculated according to Grimby and Söderळ holm (1963), Berglund et al. (1963), and Birath? Kjellmer, and Sandqvist (1963).

Airway resistance (Raw) was determined b $\vec{D}$ constant volume body plethysmography; the pre $\frac{\mathrm{Q}}{\mathrm{D}}$ dicted values are those of Amrein et al. (1970).

Diffusing properties of the lung were studied by the carbon monoxide single-breath method; the 
T A B L E I

BIOMETRIC CHARACTERISTICS OF THE SUBJECTS STUDIED

\begin{tabular}{|c|c|c|c|c|c|c|c|}
\hline Patient & Sex & $\begin{array}{c}\text { Age } \\
\text { (years) }\end{array}$ & $\begin{array}{c}\text { Height } \\
\text { (metres) }\end{array}$ & $\begin{array}{c}\text { Weight } \\
\text { (kg) }\end{array}$ & Aetiology of Shock & $\begin{array}{c}\text { Duration of } \\
\text { Artificial } \\
\text { Ventilation } \\
\text { (days) }\end{array}$ & $\begin{array}{c}\text { Duration of } \\
\text { Study after } \\
\text { 'Shock Lung' } \\
\text { (months) }\end{array}$ \\
\hline $\begin{array}{l}1 \\
2 \\
3 \\
4 \\
5 \\
6 \\
7\end{array}$ & $\begin{array}{l}\mathbf{F} \\
\mathbf{F} \\
\mathbf{F} \\
\mathbf{F} \\
\mathbf{F} \\
\mathbf{M}\end{array}$ & $\begin{array}{l}35 \\
42 \\
30 \\
29 \\
52 \\
22 \\
38\end{array}$ & $\begin{array}{l}1 \cdot 67 \\
1 \cdot 50 \\
1 \cdot 60 \\
1 \cdot 68 \\
1 \cdot 57 \\
1 \cdot 64 \\
1 \cdot 71\end{array}$ & $\begin{array}{l}60 \\
42 \\
52 \\
48 \\
56 \\
49 \\
65\end{array}$ & $\begin{array}{l}\text { Septic and hypovolaemic } \\
\text { Septic and hypovolaemic } \\
\text { Hypovolaemic with acute renal failure } \\
\text { Septic and hypovolaemic with renal failure } \\
\text { Septic with renal failure } \\
\text { Septic } \\
\text { Hypovolaemic and septic }\end{array}$ & $\begin{array}{r}13 \\
40 \\
2 \\
7 \\
3 \\
9 \\
16\end{array}$ & $\begin{array}{r}20 \\
3 \\
1 \\
3 \\
11 \\
3 \\
3\end{array}$ \\
\hline
\end{tabular}

normal values are those of Englert (1967). The transfer factor was calculated using both the effective alveolar volume measured using the dilution of helium during breath-holding $\left(\mathrm{TF}^{1}\right)$ and the alveolar volume measured by adding the inspired volume to the residual volume previously determined by the multiple-breath helium dilution method (TF).

Oesophageal pressure was measured with a Latex balloon (length $10 \mathrm{~cm}$, perimeter $5 \mathrm{~cm}$ ) containing $1 \mathrm{ml}$ of air. With the balloon in the lower third of the oesophagus, the subject breathed into a bag containing air at $37^{\circ} \mathrm{C}$ and saturated with water vapour. After a few normal breaths, during which the end expiratory level and the zero pressure were carefully noted, the subject took a full inspiration, then expired slowly to or slightly under the FRC level; during the next very slow deep inspiratory and expiratory manoeuvres (to or near residual volume level), transpulmonary pressure and volume were directly recorded on an X-Y recorder. At least two correct measurements were obtained for each subject (i.e., measurements with total lung volume very close to previously determined total lung capacity (TLC) and without evident artefact of pressure). From these tracings, static inspiratory (CLI) and expiratory (CLE) compliances were calculated from the transpulmonary pressure variation between FRC and FRC +0.5 litre. The normal values for compliance were determined in a group of 22 young adults (Yernault and Englert, 1974). Maximal inspiratory pressure (PI max) and elastic recoil at various levels of total lung capacity (Pst) were compared to the normal values established by Turner, Mead, and Wohl (1968). Finally, the coefficient of retraction (CR), according to Schlueter, Immekus, and Stead (1967), was calculated by dividing Pst at $100 \%$ TLC by TLC.

A previously described partially computerized program (Yernault et al., 1972) was used for the calculations and presentation of results.

Pulmonary scanning was performed in three patients (cases 1, 2, and 3) with a gamma camera after intravenous injection of technetium-99m labelled microspheres.

\section{RESULTS}

Table II shows the results of measurements of lung volumes: vital capacity is slightly lowered, but functional residual capacity, measured either

T A B L E I I

PULMONARY VOLUME MEASUREMENTS

\begin{tabular}{|c|c|c|c|c|c|c|c|}
\hline Patient & $\begin{array}{c}\text { Vital } \\
\text { Capacity } \\
\text { (1.) }\end{array}$ & $\begin{array}{c}\text { Functional } \\
\text { Residual } \\
\text { Capacity } \\
\text { (1.) }\end{array}$ & $\begin{array}{c}\text { Residual } \\
\text { Volume } \\
\text { (I.) }\end{array}$ & $\begin{array}{c}\text { Total Lung } \\
\text { Capacity } \\
\text { (1.) }\end{array}$ & $\begin{array}{c}\text { RV/TLC } \\
(\%)\end{array}$ & $\underset{\text { (1.) }}{\text { FEV }_{1}}$ & $\begin{array}{c}\mathrm{FEV}_{1} / \mathrm{VC} \\
(\%)\end{array}$ \\
\hline $\begin{array}{l}1 \\
2 \\
3 \\
4 \\
5 \\
6 \\
7\end{array}$ & $\begin{array}{l}3 \cdot 71(3 \cdot 84) \\
2 \cdot 35(2 \cdot 95) \\
3 \cdot 27(3 \cdot 71) \\
3 \cdot 36(4 \cdot 03) \\
2 \cdot 69(3 \cdot 02) \\
3 \cdot 57(4 \cdot 02) \\
3 \cdot 25(5 \cdot 00)\end{array}$ & $\begin{array}{l}3.59(2.42) \\
2 \cdot 25(1 \cdot 89) \\
2.97(2 \cdot 19) \\
3.09(2.49) \\
3.43(2.08) \\
2.90(2 \cdot 32) \\
3.23(3.47)\end{array}$ & $\begin{array}{l}2.05(1 \cdot 41) \\
1 \cdot 35(0.94) \\
1 \cdot 56(1 \cdot 11) \\
1 \cdot 73(1 \cdot 38) \\
1.99(1 \cdot 23) \\
1 \cdot 34(1 \cdot 16) \\
1 \cdot 71(1 \cdot 80)\end{array}$ & $\begin{array}{l}5 \cdot 76(5 \cdot 26) \\
3 \cdot 70(3 \cdot 90) \\
4 \cdot 83(4 \cdot 82) \\
5 \cdot 09(5 \cdot 40) \\
4 \cdot 68(4 \cdot 25) \\
4 \cdot 91(5 \cdot 18) \\
4 \cdot 96(6 \cdot 81)\end{array}$ & $\begin{array}{l}36(27) \\
37(24) \\
32(23) \\
34(25) \\
43(29) \\
27(22) \\
34(26)\end{array}$ & $\begin{array}{l}3 \cdot 05(3 \cdot 19) \\
1 \cdot 97(2 \cdot 40) \\
3 \cdot 17(3 \cdot 14) \\
2 \cdot 92(3 \cdot 40) \\
2 \cdot 21(2 \cdot 37) \\
3 \cdot 03(3 \cdot 47) \\
2 \cdot 30(3 \cdot 90)\end{array}$ & $\begin{array}{l}82(83) \\
84(81) \\
97(85) \\
87(85) \\
82(79) \\
85(86) \\
71(78)\end{array}$ \\
\hline $\begin{array}{l}\text { Mean observed } \\
\text { SD } \\
\text { Mean predicted } \\
\text { SD }\end{array}$ & $\begin{array}{l}3 \cdot 17 \\
0.48 \\
3 \cdot 80 \\
0.69 \\
\text { NS }\end{array}$ & $\begin{array}{l}3.07 \\
0.44 \\
2.41 \\
0.51 \\
0.025\end{array}$ & $\begin{array}{l}1 \cdot 68 \\
0.28 \\
1 \cdot 29 \\
0 \cdot 28 \\
0.025\end{array}$ & $\begin{array}{l}4.85 \\
0.61 \\
5.09 \\
0.94 \\
\text { NS }\end{array}$ & $\begin{array}{c}34 \cdot 7 \\
4 \cdot 9 \\
25 \cdot 2 \\
2 \cdot 4 \\
0 \cdot 001\end{array}$ & $\begin{array}{l}2.66 \\
0.49 \\
3 \cdot 12 \\
0.56 \\
\text { NS }\end{array}$ & $\begin{array}{c}84 \\
7 \cdot 7 \\
82 \cdot 4 \\
3 \cdot 2 \\
\text { NS }\end{array}$ \\
\hline
\end{tabular}

Predicted values are shown in parentheses. The mean value of the group studied is compared to the mean predicted value. The significance of the difference between the two groups is also reported (NS =not significant). 
by helium dilution or by body plethysmography, and residual volume (RV) are significantly increased; total lung capacity remains normal. The increase of the RV/TLC ratio is highly significant, but the ratio $\mathrm{FEV}_{1} / \mathrm{VC}$ is normal.

In Table III are recorded the diffusing properties of the lung. When calculated by the classical method, TF is slightly greater than when calculated using effective alveolar volume, but whatever the method used there is a highly significant reduction of TF. The Krogh constant (k) is also significantly lowered.

The mechanical properties are presented in Table IV. Airways resistance is normal, as are both CLI and CLE. A moderate loss of lung recoil is apparent in five patients, as shown by a low PI max and low Pst at different lung volumes (Figure). It is of interest that the only subject with

T A B L E I I I

MEASUREMENTS OF DIFFUSING PROPERTIES

\begin{tabular}{|c|c|c|c|}
\hline Patient & \multicolumn{2}{|c|}{$\begin{array}{l}\text { Transfer Factor } \\
\left(\mathrm{ml} \mathrm{min}^{-1} \mathrm{mmHg}^{-1}\right)^{1} \\
\mathrm{TF}^{1}\end{array}$} & \multirow{2}{*}{ 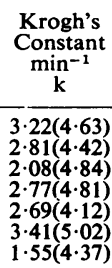 } \\
\hline $\begin{array}{l}1 \\
2 \\
3 \\
4 \\
5 \\
6 \\
7\end{array}$ & $\begin{array}{c}17 \cdot 3(26 \cdot 7) \\
10 \cdot 7(18 \cdot 5) \\
10(25 \cdot 6) \\
12 \cdot 8(25 \cdot 4) \\
12 \cdot 1(20 \cdot 3) \\
18 \cdot 5(26 \cdot 8) \\
7 \cdot 1(27 \cdot 6)\end{array}$ & $\begin{array}{l}19.9 \\
11.5 \\
10.5 \\
13.6 \\
13.7 \\
18.4 \\
-\end{array}$ & \\
\hline $\begin{array}{l}\text { Mean observed } \\
\text { SD } \\
\text { Mean predicted } \\
\text { SD }\end{array}$ & $\begin{array}{c}12 \cdot 6 \\
4 \\
24 \cdot 4 \\
3 \cdot 5 \\
0 \cdot 001\end{array}$ & $\begin{array}{c}14 \cdot 6 \\
3.8 \\
23.9 \\
3.6 \\
0.005\end{array}$ & $\begin{array}{l}2 \cdot 65 \\
0 \cdot 64 \\
4 \cdot 6 \\
0 \cdot 31 \\
0 \cdot 001\end{array}$ \\
\hline
\end{tabular}

${ }^{1}$ To convert to SI units (mmol $\left.\mathrm{min}^{-1} \mathrm{kPa}^{-1}\right)$ multiply by 0.335 . Predicted values are shown in parentheses. The mean value of the group studied is compared to the mean predicted value. The significance of the difference between the two groups is also reported. normal lung recoil had been ventilated with $\frac{\overrightarrow{\bar{\omega}}}{\overline{0}}$ residual positive expiratory pressure of $30 \mathrm{mmHg}$.

Pulmonary scanning was normal in two patients (cases 1 and 3 ) and showed heterogeneity of perfusion in one (case 2).

\section{DISCUSSION}

The diagnosis of shock lung was firmly established in all the cases reported on clinical, radiological and physiological bases. Aetiology was, however $x$ not uniform and the severity of the disease varied,, as could be judged from the varying duration of artificial ventilation needed (de Coster et al., N 1974).

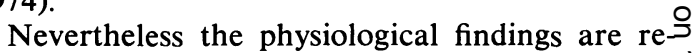
markably constant. Total lung capacity is norma but the ratio RV/TLC tends to be high; there is no sign of airway obstruction, airway resistance ${ }^{\mathbb{D}}$ and the $\mathrm{FEV}_{1} / \mathrm{VC}$ ratio being normal in all cases, $\overrightarrow{0}$ compliance is normal but there is a slight loss of lung recoil in most patients; transfer factor is strikingly reduced. Interpretation of the increases in FRC, RV, and RV/TLC must be cautious since in absolute values it is only slight and de. pends on the normal values used. For example, ifo RV is predicted according to Needham, Rogan and McDonald (1954) or to Goldman and Beck $\frac{3}{3}$ lake (1959), there is no significant variation fromb normal. Previous reports from our laboratory have drawn attention to these problems (de Coster and Schmitz-Cusnier, 1970; de Coster, Messin and̋ Degré, 1967), but recent studies (Yernault and Englert, 1974) seem to confirm the validity of the reference values which are used in the presen work.

T A B L E I V

MEASUREMENTS OF MECHANICAL LUNG PROPERTIES

\begin{tabular}{|c|c|c|c|c|c|}
\hline Patient & $\begin{array}{c}\text { Airways } \\
\text { Resistance } \\
\left(\mathrm{cmH}_{2} \mathrm{O}^{-1} \mathrm{sec}^{-1}\right)^{1}\end{array}$ & $\begin{array}{l}\text { Inspiratory } \\
\text { Quasi-static } \\
\text { Compliance } \\
\left(\mathrm{l} \mathrm{cmH}_{2} \mathrm{O}^{-1}\right)^{2}\end{array}$ & $\begin{array}{l}\text { Expiratory } \\
\text { Quasi-static } \\
\text { Compliance } \\
\left(1 \mathrm{cmH} \mathrm{H}_{2} \mathrm{O}^{-1}\right)^{2}\end{array}$ & $\begin{array}{l}\text { Transpulmonary } \\
\text { Pressure at } \\
\text { Full Inspiration } \\
\left(\mathrm{cm} \mathrm{H}_{2} \mathrm{O}\right)^{1}\end{array}$ & $\begin{array}{c}\text { Coefficient of } \\
\text { Retraction } \\
\left(\mathrm{cmH}_{2} \mathrm{O}^{-1}\right)^{1}\end{array}$ \\
\hline $\begin{array}{l}1 \\
2 \\
3 \\
4 \\
5 \\
6 \\
7\end{array}$ & $\begin{array}{l}2.4(1 \cdot 8) \\
1.5(1 \cdot 8) \\
2 \cdot 1(1 \cdot 8) \\
1.8(1 \cdot 8) \\
1.4(1 \cdot 8) \\
2.5(1 \cdot 8)\end{array}$ & $\begin{array}{l}0 \cdot 185(0 \cdot 177) \\
0 \cdot 133(0 \cdot 094) \\
0 \cdot 153(0 \cdot 143) \\
0 \cdot 136(0 \cdot 182) \\
0 \cdot 181(0 \cdot 128) \\
0 \cdot 148(0 \cdot 162) \\
-\end{array}$ & $\begin{array}{l}0.160(0.240) \\
0.174(0.125) \\
0.200(0.193) \\
0.141(0.247) \\
0.190(0.172) \\
0.181(0.220) \\
0.215(0.267)\end{array}$ & $\begin{array}{l}27 \cdot 1(33 \cdot 9) \\
18 \cdot 5(30 \cdot 9) \\
27 \cdot 8(34 \cdot 3) \\
24 \cdot 5(34 \cdot 3) \\
21 \cdot 7(26 \cdot 7) \\
35 \cdot 2(34 \cdot 3) \\
30 \cdot 1(32 \cdot 7)\end{array}$ & $\begin{array}{l}4 \cdot 8(6 \cdot 4) \\
4 \cdot 5(7 \cdot 9) \\
5 \cdot 3(7 \cdot 1) \\
5 \cdot 1(6 \cdot 4) \\
4 \cdot 4(6 \cdot 3) \\
5 \cdot 9(5 \cdot 2) \\
6 \cdot 0(4 \cdot 8)\end{array}$ \\
\hline $\begin{array}{l}\text { Mean observed } \\
\text { SD } \\
\text { Mean predicted } \\
\text { SD }\end{array}$ & $\begin{array}{l}1.95 \\
0.46 \\
1.8 \\
0 \\
\text { NS }\end{array}$ & $\begin{array}{l}0 \cdot 156 \\
0.022 \\
0 \cdot 148 \\
0.033 \\
\text { NS }\end{array}$ & $\begin{array}{l}0.180 \\
0.025 \\
0.209 \\
0.049 \\
\text { NS }\end{array}$ & $\begin{array}{l}26 \cdot 4 \\
5 \cdot 5 \\
32 \cdot 4 \\
2 \cdot 8 \\
0 \cdot 025\end{array}$ & $\begin{array}{l}5 \cdot 1 \\
0 \cdot 6 \\
6 \cdot 3 \\
1 \cdot 1 \\
\text { NS }\end{array}$ \\
\hline
\end{tabular}

To convert to SI units:

TMultiply by $0 \cdot 1\left(\mathrm{kPa}\right.$ per $\left.\mathrm{cm} \mathrm{H}_{2} \mathrm{O}\right)$.

${ }^{2}$ Multiply by $10\left(\mathrm{kPa}\right.$ per $\left.\mathrm{cm} \mathrm{H}_{2} \mathrm{O}\right)$.

Predicted values are shown in parentheses. The mean value of the group studied is compared to the mean predicted value. The significance of the difference between the two groups is also reported (NS $=$ not significant). 

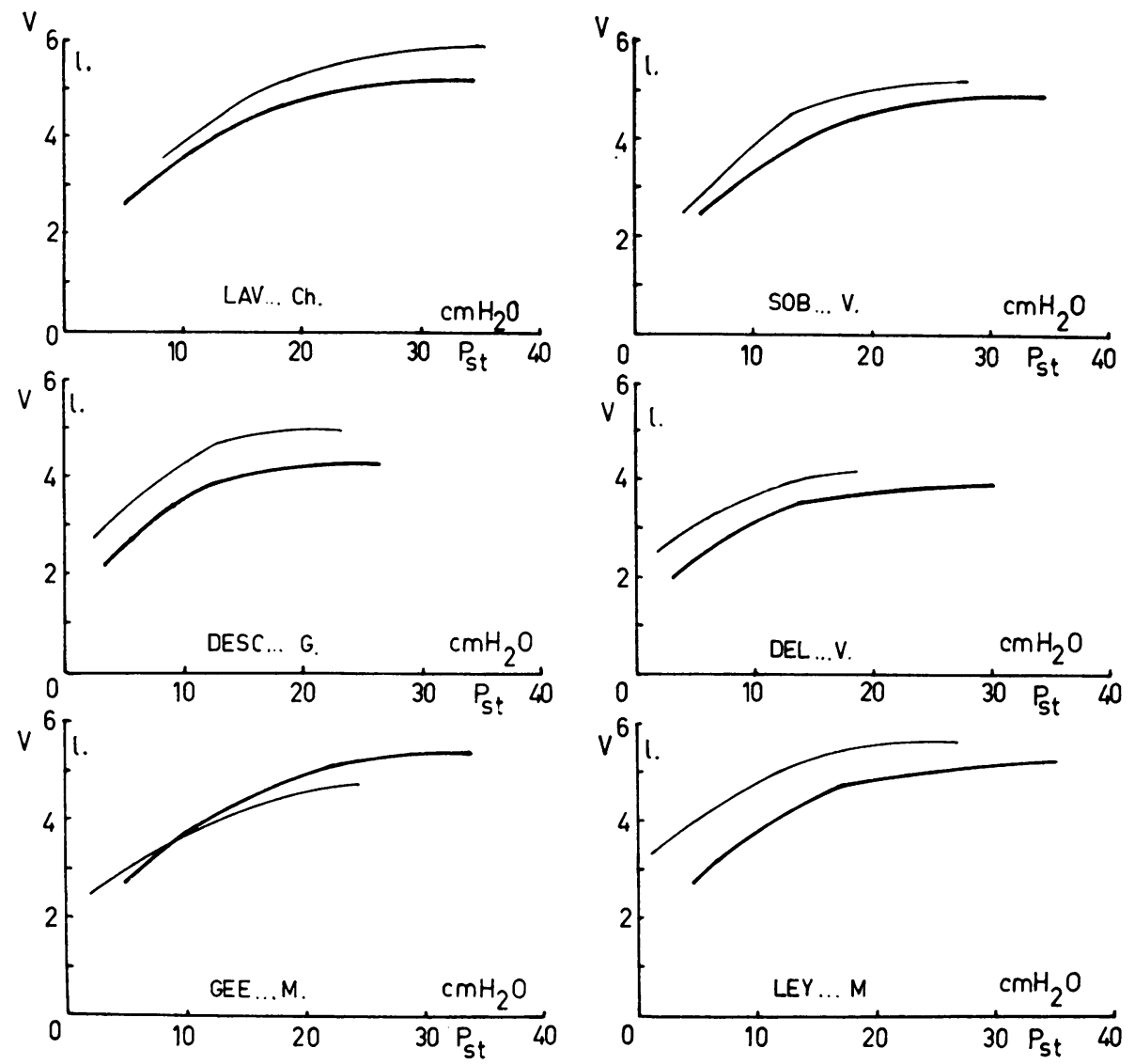

FIGURE Representation of volume-pressure curves of the subjects studied. The thick line is the predicted curve, the thin line the measured one.

These borderline abnormalities in FRC, RV, and RV/TLC could be related to the loss of lung recoil. It is not, however, of sufficient degree to suggest pulmonary emphysema, although in patients who died from 'solid lung', Wyatt (1973) described overexpansion of air ducts and air sacs in the unconsolidated areas. The most likely explanation seems a modification in lung surface properties: such modifications have indeed been induced experimentally by tracheal obstruction in dogs in vivo (Buhain, Brody, and Fisher, 1972) or by ventilation of excised dog lungs with an end expiratory pressure of $7 \mathrm{cmH}_{2} \mathrm{O}$ (Raimondi, Massarella, and Pride, 1971).

The important reduction of transfer factor of the lung is the most characteristic feature in all patients. Few studies have as yet been performed in this field. Interiano, Stuard, and Hyde (1972) showed a reduction of the diffusing capacity of the lung in one patient, studied after acute respiratory distress following acute pancreatitis. Downs and Olsen (1974) also reported a transient reduction of TF in one patient after adult respiratory distress syndrome. In the present series also the lowest values of TF are seen soon after the acute phase.

The reduction of diffusing capacity of the lung is probably related to disturbances at the capillary level. Extensive pulmonary arterial thrombosis can be excluded by the studies of the distribution of pulmonary perfusion performed in three cases, but diffuse thrombosis or destruction of the capillaries are known to occur during the acute phase of the disease (Hardaway et al., 1967; Dalldorf et al., 1968; Martin, Soloway, and Simmons, 1968; Groves et al., 1972; Pariente et 
al., 1972). From the present results it appears that these disturbances are, at least partly, irreversible.

It should be emphasized that these disturbances of diffusing properties of the lung are present without any sign of pulmonary fibrosis, which is known to develop in fatal cases (Hardaway et al., 1967; Wilson et al., 1969; Bredenberg et al., 1969): pulmonary compliance and total lung capacity are indeed perfectly normal in all seven cases.

Although definite, the reported changes of lung function seem not to be of major clinical significance since $\mathrm{PaO}_{2}$ at rest was normal in each patient before discharge from hospital. The long-term evolution is, however, impossible to predict and needs further studies.

\section{REFERENCES}

Amrein, R., Keller, R., Joos, H., and Herzog, H. (1970). Valeurs normales de l'exploration de la fonction pulmonaire par la pléthysmographie corporelle. Journal Français de Médecine et Chirurgie Thoraciques, 24, 245.

Berglund, E., Birath, G., Bjure, J., Grimby, G., Kjellmer, I., Sandqvist, L., and Söderholm, B. (1963). Spirometric studies in normal subjects. Forced expirograms in subjects between 7 and 70 years of age. Acta Medica Scandinavica, 173, 185.

Birath, G., Kjellmer, I., and Sandqvist, L. (1963). Spirometric studies in normal subjects. Ventilatory capacity tests in adults. Acta Medica Scandinavica, 173, 193.

Bredenberg, C. E., James, P. M., Collins, J., Anderson, R. W., Martin, A. M., and Hardaway, R. M. (1969). Respiratory failure in shock. Annals of Surgery, 169, 392.

Buhain, W. J., Brody, J. S., and Fisher, A. B. (1972). Effect of artificial airway obstruction on elastic properties of the lung. Journal of Applied Physiology, 33, 589.

Cahill, J. M., Jouasset-Strieder, D., and Byrne, J. J. (1965). Lung function in shock. American Journal of Surgery, 110, 324.

Dalldorf, F. G., Carney, C. N., Rackley, C. E., and Raney, R. B. (1968). Pulmonary capillary thrombosis in septicemia due to Gram-positive bacteria. Journal of the American Medical Association, 206, 583.

de Coster, A., Messin, R., and Degré, S. (1967). Interprétation des résultats spirographiques. Acta Tuberculosa et Pneumologica Belgica, 58, 557.

and Schmitz-Cusnier, C. (1970). Les volumes pulmonaires de la femme: variations physiologiques. In Normal Values for Respiratory Function in Man, edited by P. Arcangeli, J. E. Cotes, A. Cournand, H. Denolin, G. Di Maria, P. Sadoul, M. Scherrer, and G. L. Scarpa, pp. 154-169. Panminerva Medica, Rome. Englert, M. (1974). Le concept du poumon de choc. Lille Médical, 19, 424.

Downs, J. B. and Olsen, G. N. (1974). Pulmonary function following adult respiratory distress $\mathbb{\otimes}$ syndrome. Chest, 65, 92.

Englert, M. (1967). Le Réseau Capillaire Pulmonaire ڤ chez l'Homme. Masson, Paris.

Gay, R. and Campan, L. (1972). Manifestations pul- $\vec{\overrightarrow{ }}$ monaires des états de choc: poumon de choc? $\vec{\omega}$ Bulletin de Physio-pathologie Respiratoire, 8, 731.

Goldman, H. I. and Becklake, M. R. (1959). Respiratory function tests. Normal values at median altitudes and the prediction of normal results. is American Review of Respiratory Diseases, 79, N 457.

Grimby, G. and Söderholm, B. (1963). Spirometric studies in normal subjects: static lung volumesand maximum voluntary ventilation in adults with $\subsetneq$ a note on physical fitness. Acta Medica Scandinavica, 173, 199.

Groves, A. C., Griffiths, J., Leung, F. Y. T., and $\vec{\bullet}$ Naiman, S. C. (1972). Fibrin thrombi in the pulmonary microcirculation of dogs with Gramnegative bacteremia. Surgery, Gynecology ando Obstetrics, 134, 433.

Hardaway, R. M., James, P. M., Anderson, R. W. Bredenberg, C. E., and West, R. L. (1967) Intensive study and treatment of shock in man $\mathbb{Q}$ Journal of the American Medical Association 199, 779.

Henry, J. N., McArdle, A. H., Scott, H. J., and Gurd, F. N. (1967). A study of the acute and chronic respiratory pathophysiology of hemoro rhagic shock. Journal of Thoracic and Cardio vascular Surgery, 54, 666.

Interiano, B., Stuard, I. D., and Hyde, R. W. (1972) Acute respiratory distress syndrome in pan creatitis. Annals of Internal Medicine, 77, 923.

Martin, A. M., Soloway, H. B., and Simmons, R. L' (1968). Pathologic anatomy of the lungs follow ing shock and trauma. Journal of Trauma, 8 , 687.

Moore, F. D., Lyons, J. H., Pierce, E. C., Morgan A. P., Drinker, P. A., MacArthur, J. D., an Dammin, G. J.'(1969). Posttraumatic Pulmonar Insufficiency. Saunders, Philadelphia.

Needham, C. D., Rogan, M. C., and McDonald, N (1954). Normal standards for lung volumens intrapulmonary gas-mixing, and maximurfy breathing capacity. Thorax, 9,313 .

Pariente, R., André, J., Legrand, M., and Brouet, $\mathscr{q}$ (1972). Les lésions élémentaires ultrastructuraleẹ du poumon. Nouvelle Presse Médicale, 1, 135

Proctor, H. J., Ballantine, T. V. N., and Broussard N. D. (1970). An analysis of pulmonary function following non-thoracic trauma, with recong mendations for therapy. Annals of Surgery, 17 180.

Raimondi, A. C., Massarella, G. R., and Pride, N. B. (1971). The effects of ventilation on the elastig 
recoil of excised dogs' lungs. Respiration Physiology, 12, 205.

Schlueter, D. P., Immekus, J., and Stead, W. W. (1967). Relationship between maximal inspiratory pressure and total lung capacity (coefficient of retraction) in normal subjects and patients with emphysema, asthma, and diffuse pulmonary infiltration. American Review of Respiratory Diseases, 96, 656.

Turner, J. M., Mead, J., and Wohl, M. E. (1968). Elasticity of human lungs in relation to age. Journal of Applied Physiology, 25, 664.

Wilson, R. F., Kafi, A., Asuncion, Z., and Walt, A. J. (1969). Clinical respiratory failure after shock or trauma. Archives of Surgery, 98, 539.

Wyatt, J. P. (1973). Lung patterns in emphysema.
Bulletin de Physio-pathologie Respiratoire, 9, 925.

Yernault, J. C., Baran, D., Englert, M., and Derckx, C. (1972). Un programme partiellement automatisé d'étude fonctionnelle pulmonaire. Application chez l'adulte et l'enfant. Acta Tuberculosa et Pneumologica Belgica, 63, 110.

- and Englert, M. (1974). Static mechanical lung properties in young adults. Bulletin de Physiopathologie Respiratoire, 10, 435.

Requests for reprints to: Dr. J. C. Yernault, Departments of Pneumology and Cardiology, Hôpital Universitaire Saint Pierre, Rue Haute, 322, 1000 Brussels, Belgium. 